\title{
PENDUGAAN KARBON TERSIMPAN PADA TEGAKAN DI KAWASAN ARBORETUM SYLVA UNIVERSITAS TANJUNGPURA
}

\author{
(Estimation of Aboveground Stored Carbon Stocks in the Arboretum Sylva of Universitas \\ Tanjungpura)
}

\author{
Priska Suryandari, Dwi Astiani, Iswan Dewantara \\ Fakultas Kehutanan Universitas Tanjungpura Pontianak, Jl. Daya Nasional Pontianak 78124 \\ Email: yandapriska@gmail.com
}

\begin{abstract}
Indonesia's tropical forests have an important large amounts of carbon and biodiversity land. The landcover change of the forest for other uses such as agriculture or plantations, particularly in the carbon-rich peat land, making Indonesia become one of the biggest greenhouse gas emitters in the world. Along with the increase of the earth's temperature that rising quite sharply in recent years, Arboretum storage development programs are important in reducing air pollution. Arboretum storage created as a buffer area for water needs, natural environment and carbon storage as well as a have for the flora and fauna in urban areas. One of the Arboretum in the province of West Kalimantan is the area Arboretum Sylva Faculty of forestry Universitas of Tanjungpura Pontianak. The area is an planted with trees and other vegetation forming a structure resembling a forests and an area for the conservation of forest germplasm. It is needed to do re-measurement to search for the growth of the carbon stock in the Arboretum Sylva Tanjungpura University during a period of six years after the initial measurement. This research aims to register total value of (carbon stock) in the area of the Arboretum of the University of Tanjungpura Sylva. The method used for the research was survey sampling with non destructive measurement assesment for tree stage. Data collection was done by census/sampling intensity (100\%). While for the level of sapling, pole stage, stake and necromass were done by nested plots. The results show carbon stock stored for the per unit area was 255.55 tons/Ha and the value of carbon stored whole area was 817.76 Tons.
\end{abstract}

Keywords: stored carbon, tropical forests, Urban forests

\section{PENDAHULUAN}

Hutan merupakan sumberdaya alam yang mempunyai fungsi ekonomi, ekologi, sosial dan budaya yang diperlukan untuk menunjang secara langsung dan tidak langsung kehidupan manusia dan makhluk hidup lainnya (Arief, 1994). Hutan tropis Indonesia memiliki simpanan karbon dalam jumlah besar dan keanekaragaman hayati yang penting. Hutan berperan penting dalam menjaga kestabilan iklim global. Secara kimiawi, vegetasi hutan akan menyerap gas karbon $\left(\mathrm{CO}_{2}\right)$ melalui proses fotosintesis. Jika hutan terganggu maka siklus $\mathrm{CO}_{2}$ dan $\mathrm{O}_{2}$ di atmosfer akan terganggu. Umumnya karbon tersimpan dalam biomasa vegetasi, serasah, nekromasa (baik diatas permukaan dan dalam tanah) dan bahan organik tanah di dalam ekosistem hutan. Biomassa adalah kunci penting dalam menilai suatu ekosistem. Informasi tentang biomassa di atas tanah (aboveground biomass, AGB) diperlukan untuk memperkirakan dan 
memprediksi produktivitas ekosistem, simpanan karbon, pembagian unsur hara dan akumulasi bahan bakar (Brown 2002). Seiring dengan peningkatan suhu bumi yang meningkat cukup tajam dalam beberapa tahun terakhir, maka program pembangunan hutan kota sangat berperan penting dalam mengurangi polusi udara. Hutan kota dibuat sebagai daerah penyangga kebutuhan air, lingkungan alami dan penyimpan/ pengikat karbon serta pelindung flora dan fauna di perkotaan. (Nazaruddin, 1994).

Salah satu hutan kota yang ada di Provinsi Kalimantan Barat adalah kawasan Arboretum Sylva Universitas Tanjungpura yang merupakan sebuah kawasan ditanami pepohonan dan tumbuhan lainnya sehingga membentuk struktur menyerupai hutan dan sebuah kawasan untuk pelestarian plasma nutfah. Tujuan dari penelitian ini adalah untuk mendata/mendapatkan informasi total rerata nilai karbon yang tersimpan (carbon stock) di kawasan Arboretum Sylva Fakultas Kehutanan Universitas Tanjungpura Pontianak Kalimantan Barat. Dengan berjalannya waktu perlu dilakukan pengukuran kembali untuk mengetahui perkembangan stok karbon di Arboretum Sylva Universitas Tanjungpura selama jangka waktu enam tahun setelah pengukuran awal. Manfaat dari penelitian ini adalah agar dapat memberikan data mengenai karbon tersimpan (carbon stock) setelah enam tahun untuk mengukur kemampuan hutan kota Arboretum dalam menyangga dan menangkap karbon dan berguna dalam pengelolaan dan pengembangan kawasan Arboretum Sylva Universitas Tanjungpura.

\section{METODE PENELITIAN}

Penelitian ini dilakukan pada bulan Juni sampai dengan Juli 2017 di kawasan Arboretum Sylva Universitas Tanjungpura yang berada di Pontianak, Kalimantan Barat. Alat dan bahan yang digunakan dalam penelitian ini adalah Thally sheet, alat tulis, Kompas, GPS, Meteran, Pita ukur / phiband, Hagameter, Kamera digital.

Untuk penentuan posisi plot penelitian dibuat dengan lebar ukuran $20 \mathrm{~m}$ dan panjangnya disesuaikan dengan batas luas areal Arboretum Sylva Universitas Tanjungpura. Plot penelitian ini berbentuk persegi panjang dengan petak ukuran $20 \mathrm{~m}$ x $20 \mathrm{~m}$ untuk pengukuran diameter pohon dan petak ukuran $10 \mathrm{~m}$ x $10 \mathrm{~m}$ dalam sumbu jalur untuk mengukur tiang yang mempunyai ukuran diameter batang $10-20 \mathrm{~cm}$. Untuk tingkat pancang dibuat 2 - 4 petak ukuran $5 \mathrm{~m} \times 5 \mathrm{~m}$ didalam jalur pada sumbu jalur. Pengukuran necromass dilakukan pembuatan pada jalur selebar $5 \mathrm{~m} \quad(2,5 \mathrm{~m}$ kiri kanan sumbu jalur), di dalam jalur akan diukur semua pohon mati berdiri (SWD) dan rebah (CWD) dengan diameter $>10 \mathrm{~cm}$. Pada penelitian ini menggunakan 15 jalur pengamatan dengan 2 jenis jalur yang berbeda dan panjang jalur yang disesuaikan dengan luasan Arboretum, dimana setiap jalur mempunyai peruntukan pengukuran yang berbeda. 


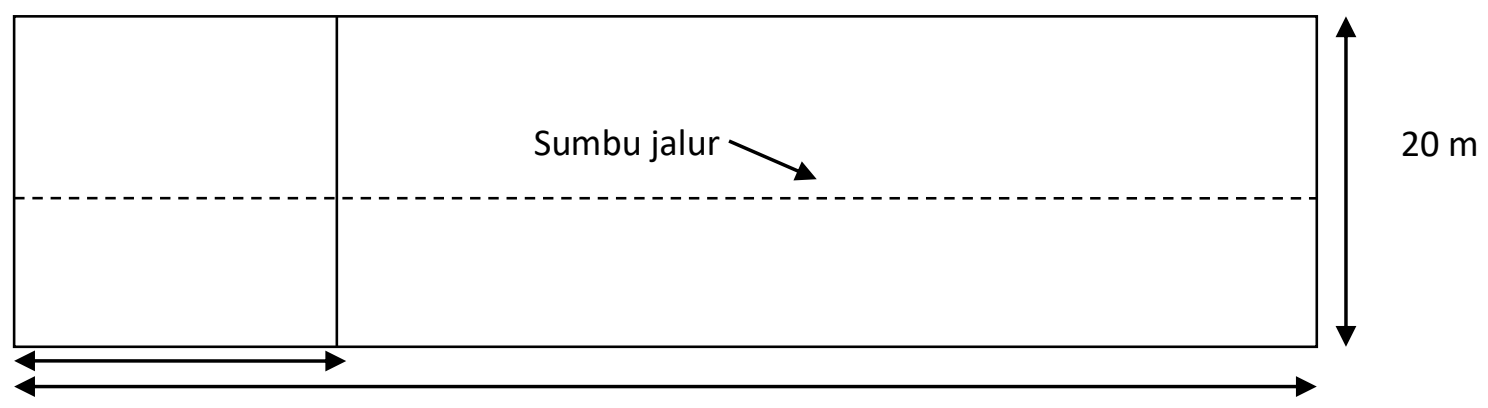

Panjang disesuaikan dengan batas luas areal Arboretum

Gambar 1. Sketsa pembuatan plot untuk pengukuran diameter pohon

Pada jalur penelitian diatas digunakan untuk pengukuran pohon yang mempunyai diameter $>20 \mathrm{~cm}$, panjang jalur yang digunakan sepanjang $100 \mathrm{~m}$ dengan lebar masing - masing petak $20 \mathrm{~m}$. Sedangkan untuk tingkat tiang, pancang dan necromassa dilakukan dengan pengambilan contoh (sampling) dengan metode tersarang didalam jalur. Untuk penentuan posisi plot penelitian dibuat dengan lebar ukuran $20 \mathrm{~m}$ dan panjangnya disesuaikan dengan batas luas areal Arboretum Sylva Universitas Tanjungpura. Jumlah plot penelitian yaitu 15 jalur dimana peletakan jalur penelitian dilakukan secara bergantian.

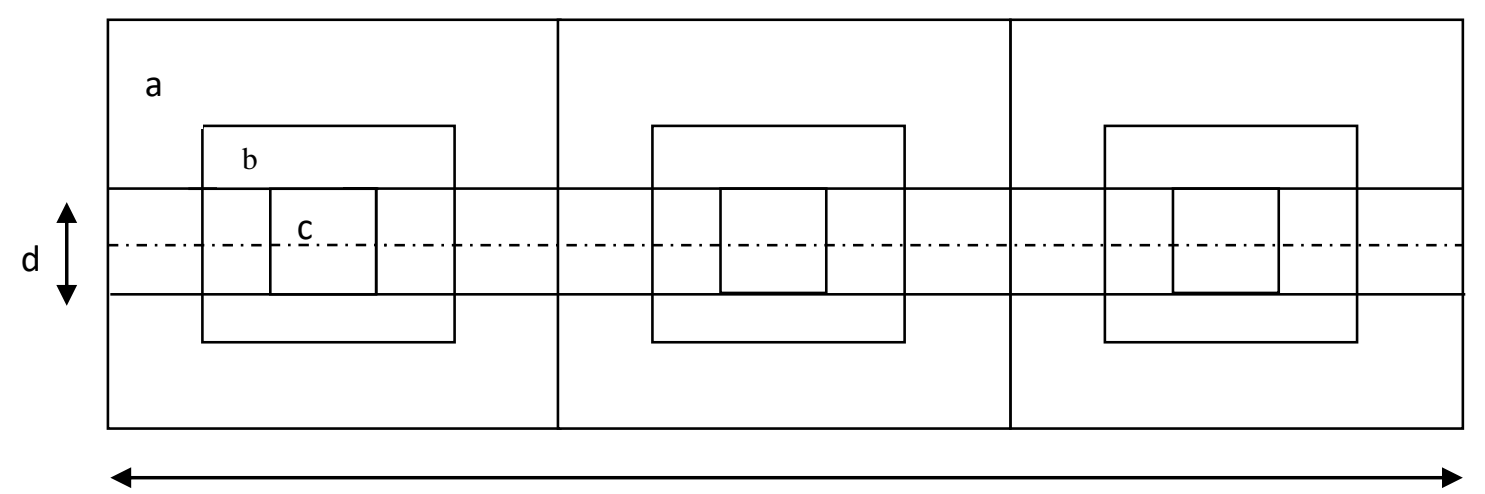

Panjang disesuaikan dengan batas luas areal

Gambar 2. Sketsa pembuatan plot untuk pengukuran diameter pohon, tiang, pancang dan necromassa

Keterangan :

a : Petak pengamatan $20 \mathrm{~m}$ x $20 \mathrm{~m}$ untuk pengamatan tumbuhan tingkat pohon.

$\mathrm{b}$ : Petak pengamatan $10 \mathrm{~m} \times 10 \mathrm{~m}$ untuk pengamatan tumbuhan tingkat tiang.

$\mathrm{c}$ : Petak pengamatan $5 \mathrm{~m} \times 5 \mathrm{~m}$ untuk pengamatan tumbuhan tingkat pancang.

$\mathrm{d}$ : Petak pengamatan $5 \mathrm{~m}$ x panjang yang disesuaikan dengan batas areal Arboretum untuk pengamatan nekromassa.

Dalam pengukuran diameter pohon $(d b h)$ idealnya diameter diukur $1,3 \mathrm{~m}$ dari permukaan tanah. Namun kenyataannya dilapangan tidak semua 
pohon dapat diukur dengan jarak 1,3 m dari permukaan tanah. Ada beberapa faktor yang menyebabkan hal itu terjadi, misalnya kondisi pohon yang berbanir, adanya percabangan kurang dari 1,3 m dari permukaan tanah dan lain sebagainya. Untuk mengatasi hal tersebut, ada beberapa cara yang harus diterapkan antara lain dengan menambahkan $0,5 \mathrm{~m}$ lagi dari jarak ideal pengukuran diameter. Menurut Weyerhaeuser dan Tennigkeit, (2000) yang dikutip oleh Hairiah K dan Rahayu S, (2007), cara pengukuran diameter pohon dapat di lihat pada gambar berikut ini.

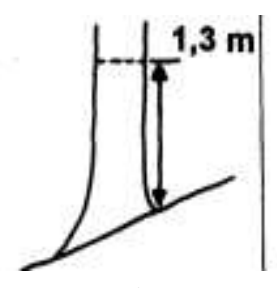

A

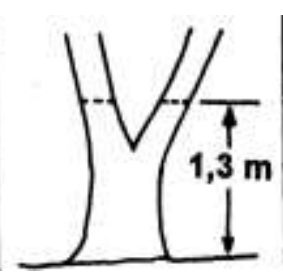

B

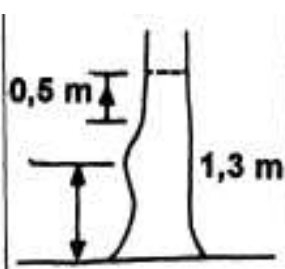

C

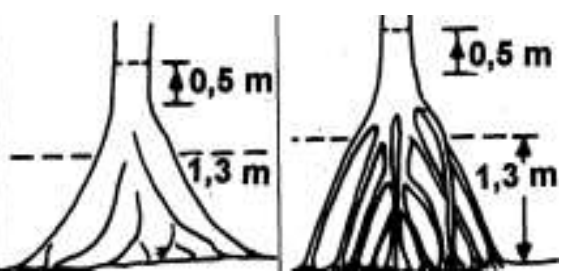

D
$\mathrm{E}$

Gambar 3. Cara menentukan ketinggian pengukuran diameter batang pohon yang tidak beraturan bentuknya

Keterangan :

a. Pohon pada tanah berlereng, pengukuran diameter pohon dilakukan $1.3 \mathrm{~m}$ pada lereng bagian atas.

b. Pohon bercabang pengukuran diameter pohon dilakukan sebelum ketinggian $1.3 \mathrm{~m}$ dan semua cabang yang ada diukur.

c. Bila pada ketinggian $1.3 \mathrm{~m}$ terdapat benjolan, maka pengukuran diameter dilakukan pada $0.5 \mathrm{~m}$ setelah benjolan.

d. Bila pada ketinggian $1.3 \mathrm{~m}$ terdapat banir (batas akar papan), maka pengukuran diameter dilakukan pada $0.5 \mathrm{~m}$ setelah banir. Namun bila banir tersebut mencapai ketinggian $>3 \mathrm{~m}$, maka diameter batang diestimasi.

e. Bila pada ketinggian $1.3 \mathrm{~m}$ terdapat akar-akar tunjang, maka pengukuran diameter dilakukan pada $0.5 \mathrm{~m}$ setelah perakaran.

Pengukuran biomassa pohon mati (necromass), metode yang digunakan pada saat dilapangan yaitu metode non destructive sampling atau metode tanpa pemanenan. Metode ini lebih menekankan pada diameter pohon sebagai indikasi perhitungan karbon tersimpan di atas permukaan tanah (above ground carbon stock) dengan menggunakan persamaan allometrik untuk pohon mati rebah ( $c w d)$, perhitungan volume dan kerapatan massa kayu.

Menurut Sutaryo D (2009), untuk pohon mati tegak ( $s w d)$, diukur diameternya $>10 \mathrm{~cm}$ dan dicatat tingkat dekomposisinya. Tingkat dekomposisi bisa dilihat dari cabang dan ranting yang masih tersisa. Empat (4) tingkat dekomposisi tersebut adalah: 
1. Kayu mati tegak dengan cabang dan ranting, seperti pohon hidup tetapi tidak berdaun (eliminasi 5\%).

2. Kayu mati dengan cabang besar dan kecil tetapi tanpa ranting (eliminasi $15 \%)$.

3. Kayu mati hanya dengan cabang besar (eliminasi 20\%).

4. Kayu mati hanya batang utama.

Jika tersedia persamaan allometrik untuk pohon mati, biomassa dapat dihitung dengan persamaan tersebut. Jika tidak tersedia, perlakuan untuk pohon mati dapat disamakan dengan pohon hidup dengan mengeliminasi komponen yang hilang. Khusus untuk kayu mati dengan hanya meninggalkan cabang utama (tingkat 4), apabila kondisinya sudah sangat lapuk dapat diperlakukan seperti kayu mati yang rebah, untuk itu harus dicatat tinggi batang dan diameter pada pangkal batang, sedangkan pengukuran pohon mati rebah ( $c w d)$ meliputi panjang, diameter pangkal, diameter ujung dan kelas kelapukan yang terdiri dari tiga kelas.

Kelas satu dengan kelapukan $0-30$ $\%$, dengan ciri-ciri pohon baru tumbang, kayu bulat utuh, warna kayu masih asli, cabang masih ada dan ranting masih menyatu dan mempunyai kulit yang kencang, sulit untuk dipatahkan, tidak ada bagian yang membusuk. kelas kedua dengan kelapukan $30-70 \%$ dengan ciri-ciri hampir membusuk tetapi tidak bisa dilepaskan dengan tangan, beberapa ranting terlepas dan kulit kayu ada yang terkelupas. Kelas ketiga dengan kelapukan 70 - $100 \%$ dengan ciri-ciri bagian dalam kayu membusuk, mudah di patahkan, bentuk kayu tidak utuh, cabang yang masih ada umumnya sudah membusuk.

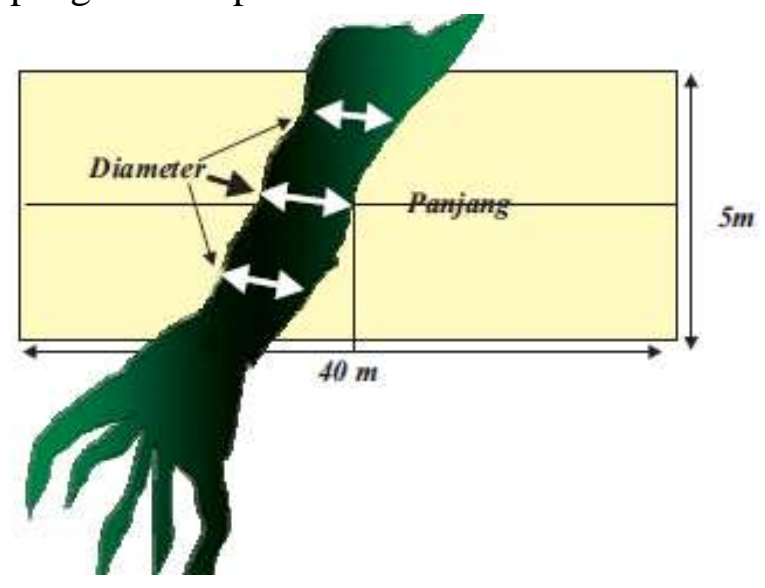

Gambar 4. Pengukuran diameter dan panjang pohon roboh yang masuk dalam sub plot utama pengamatan

Pengkuran sampel kerapatan jenis kayu, sampel yang diambil masingmasing kelas kelapukan 5 sampel dengan panjang $20 \mathrm{~cm}$ dan diukur diameter serta panjangnya untuk mendapatkan volume sampel. Khusus untuk kelas kelapukan tiga, pengukuran volume digunakan cara perendaman 
dengan asumsi air yang naik sama dengan volume kayu tersebut. Kemudian sampel tersebut di oven untuk mendapatkan berat kering oven dari masing-masing kelas kelapukan kayu. Untuk pohon mati rebah ( $c w d)$ perlu pengambilan sampel. Hal ini dilakukan untuk mengetahui kerapatan jenis kayu berdasarkan kelas pelapukannya.

Pembuatan jalur diawali dengan pengambilan starting point (SP) menggunakan GPS dengan posisi koordinat S. $00^{\circ} 03.454^{\prime}$ dan E. $109^{\circ} 21$ 053', kemudian pembuatan jalur menggunakan kompas dengan azimut $211^{\circ}$. Jalur dibuat dengan lebar $20 \mathrm{~m}$ dan panjang disesuaikan dengan batas areal arboretum dengan lahan fakultas pertanian. Metode yang digunakan adalah metode sensus (intensitas sampling 100\%). Vegetasi yang termasuk dalam penelitian yaitu tingkat pancang dengan diameter $5 \mathrm{~cm}-10 \mathrm{~cm}$, tiang dengan diameter $10 \mathrm{~cm}-20 \mathrm{~cm}$, pohon dengan diameter $>20 \mathrm{~cm}$ dan pohon mati atau nekromassa baik yang masih tegak maupun yang sudah rebah atau tumbang dengan diameter $>10 \mathrm{~cm}$ diukur dan dicatat diameternya. Pada penelitian ini terdapat 15 jalur penelitian.

\section{Analisi Data}

Data-data hasil penelitian ini berupa diameter pohon, selanjutnya biomassa tegakan diperoleh dari analisa dengan menggunakan persamaan allometrik menurut Chave et al, (2005) adalah sebagai berikut :

$$
(\text { AGB }) \text { est }=\rho * \exp \left(-1,499+2,148 * \operatorname{In}(D)+0,207 *(\operatorname{In}(D))^{2}-0,0281 *(\operatorname{In}(D))^{3}\right)
$$

Keterangan :

AGB $($ Above Ground Biomassa) $=$ Biomassa diatas permukaan tanah

$\mathrm{D}=$ Diameter Pohon $(\mathrm{cm})$

$\rho=$ Berat jenis kayu

\section{HASIL DAN PEMBAHASAN}

\section{Keanekaragaman Vegetasi}

Berdasarkan hasil identifikasi yang dilakukan, di kawasan Arboretum diperoleh 66 jenis vegetasi baik tingkat pancang (sapling), tiang (pole) maupun pohon (tree). Jenis vegetasi yang dominan terdapat di kawasan Arboretum seperti: Macaranga hosei, Melicope elleryana, Acacia mangium, Acacia auriculiformis, Gmelina arborea dan Vitex pubescens. Total vegetasi pada seluruh jalur penelitian untuk tingkat pancang, tiang dan pohon adalah 583 batang. Terdapat beberapa jenis pohon yang dilindungi seperti pohon ulin dan meranti. Kondisi vegetasi tersebut dapat mewakili keragaman flora Kalimantan. Menurut Whitemore (1984) yang dikutip oleh Krisnawati H (2003), Hutan Kalimantan dikenal secara luas sebagai salah satu pusat keragaman flora yang paling penting di Dunia selain sebagai pusat penyebaran dan keragaman jenis untuk sejumlah suku dan marga.

\section{Pendugaan Nilai Karbon Tersimpan (Carbon Stock)}

a. Pendugaan Nilai Karbon Tersimpan (Carbon Stock) per Satuan Luas 
(Ton/Ha) dan Karbon Tersimpan Keseluruhan (Ton) pada Tingkat
Pohon, Tiang dan Pancang Di Atas Permukaan Tanah.

Tabel 1. Hasil perhitungan karbon tersimpan per satuan luas (Ton/Ha) dan karbon tersimpan keseluruhan (Ton) pada tingkat pohon, tiang dan pancang di atas permukaan tanah (The results of calculations of carbon stored per unit area (Ton/Ha) and carbon stored whole (tons) at the level of the tree, a pole and a stake above ground level)

\begin{tabular}{|c|c|c|c|c|c|c|c|c|c|}
\hline No. & $\begin{array}{c}\text { Tingkat } \\
\text { Biomassa }\end{array}$ & $\begin{array}{c}\text { Total } \\
\text { Biomassa } \\
\text { Keseluruhan } \\
(\mathrm{Kg})\end{array}$ & $\begin{array}{l}\text { Total } \\
\text { Luas } \\
(\mathrm{Ha})\end{array}$ & $\begin{array}{c}\text { Biomassa } \\
\text { per Satuan } \\
\text { Luas } \\
(\mathrm{Kg} / \mathrm{Ha})\end{array}$ & SNI & $\begin{array}{c}\text { Karbon } \\
\text { Tersimpan } \\
\text { per Satuan } \\
\text { Luas } \\
(\mathrm{Kg} / \mathrm{Ha})\end{array}$ & $\begin{array}{c}\text { Karbon } \\
\text { Tersimpan } \\
\text { (Kg) }\end{array}$ & $\begin{array}{c}\text { Karbon } \\
\text { Tersimpan } \\
\text { per Satuan } \\
\text { Luas } \\
\text { (Ton/Ha) }\end{array}$ & $\begin{array}{c}\text { Karbon } \\
\text { Tersimpan }\end{array}$ \\
\hline 1. & Pohon & $1.710 .235,83$ & 3,2 & $534.448,70$ & 0,47 & $251.190,89$ & $803.810,84$ & 251,19 & 803,81 \\
\hline 2. & Tiang & $21.363,76$ & 3,2 & $6.676,18$ & 0,47 & $3.137,80$ & $10.040,97$ & 3,14 & 10,04 \\
\hline 3. & Pancang & $8.320,05$ & 3,2 & $2.600,02$ & 0,47 & $1.222,01$ & $3.910,42$ & 1,22 & 3,91 \\
\hline \multicolumn{8}{|c|}{ Total } & 255,55 & 817,76 \\
\hline
\end{tabular}

Kandungan karbon tersimpan diasumsikan $50 \%$ dari total biomassa makhluk hidup (Brown 1997). Untuk vegetasi tingkat pohon dengan diameter $>20 \mathrm{~cm}$ diperoleh karbon tersimpan sebesar 803,81 Ton. Untuk vegetasi tingkat tiang dengan diameter $10-20 \mathrm{~cm}$ diperoleh karbon tersimpan sebesar 10,04 Ton. Untuk vegetasi tingkat pancang dengan diameter $5-10 \mathrm{~cm}$ diperoleh karbon tersimpan sebesar 3,91 Ton. Karbon tersimpan yang paling besar di Kawasan Arboretum adalah pada tingkat pohon yaitu sebesar 803,81 Ton. Menurut Mansur dan Tuhteru (2010), faktor yang mempengaruhi pohon dalam menyimpan karbon lebih banyak dibandingkan dengan fase tiang, pancang dan semai yaitu karena umur pohon, dimana semakin tua umur suatu pohon maka akan semakin bertambah diameter dan tinggi pohon tersebut. Pohon dengan diameter besar dapat menyimpan lebih banyak karbon karena kontribusi utama biomasa yaitu pada batang.

b. Pendugaan Nilai Karbon Tersimpan (Carbon Stock) per Satuan Luas (Ton/Ha) dan Karbon Tersimpan Keseluruhan (Ton) pada Pohon Mati (Necromassa) Di Atas Permukaan Tanah. 
Tabel 2. Hasil perhitungan karbon tersimpan per satuan luas (Ton/Ha) dan karbon tersimpan keseluruhan (Ton) pada pohon mati (Necromass) di atas permukaan tanah (The results of calculations of carbon stored per unit area (Ton/Ha) and carbon stored whole (tons) on a dead tree (Necromass) above ground level)

\begin{tabular}{|c|c|c|c|c|c|c|c|c|c|}
\hline No. & $\begin{array}{c}\text { Tingkat } \\
\text { Biomassa }\end{array}$ & $\begin{array}{c}\text { Total } \\
\text { Biomassa } \\
\text { Keseluruhan } \\
(\mathrm{Kg})\end{array}$ & $\begin{array}{l}\text { Total } \\
\text { Luas } \\
(\mathrm{Ha})\end{array}$ & $\begin{array}{c}\text { Biomassa } \\
\text { per Satuan } \\
\text { Luas } \\
(\mathrm{Kg} / \mathrm{Ha})\end{array}$ & SNI & $\begin{array}{c}\text { Karbon } \\
\text { Tersimpan } \\
\text { per Satuan } \\
\text { Luas } \\
(\mathrm{Kg} / \mathrm{Ha})\end{array}$ & $\begin{array}{c}\text { Karbon } \\
\text { Tersimpan } \\
(\mathrm{Kg})\end{array}$ & $\begin{array}{c}\text { Karbon } \\
\text { Tersimpan } \\
\text { per Satuan } \\
\text { Luas } \\
\text { (Ton/Ha) }\end{array}$ & $\begin{array}{c}\text { Karbon } \\
\text { Tersimpan } \\
\text { (Ton) }\end{array}$ \\
\hline 1. & $\begin{array}{l}\text { Pohon } \\
\text { mati tegak } \\
\text { (SWD) }\end{array}$ & $170.990,12$ & 3,2 & $53.434,41$ & 0,47 & $25.114,17$ & $80.365,36$ & 25,11 & 80,36 \\
\hline 2. & $\begin{array}{l}\text { Pohon } \\
\text { mati rebah } \\
(\mathrm{CWD})\end{array}$ & $1.057 .445,53$ & 3,2 & $330.451,71$ & 0,47 & $155.312,30$ & $496.999,40$ & 155,31 & 155,31 \\
\hline \multicolumn{8}{|c|}{ Total } & 180,42 & 235,67 \\
\hline
\end{tabular}

Dari hasil penelitian diperoleh nilai karbon tersimpan (carbon stock) per Satuan luas sebesar 255,55 Ton/Ha dan nilai karbon tersimpan keseluruhan pada sebesar 817,76 Ton di kawasan Arboretum Sylva Fakultas Kehutanan. Sedangkan berdasarkan data sekunder Lesmana (2011) potensi karbon per Satuan luas pada sebesar 70,91 ton/Ha dan karbon tersimpan sebesar 226,90 Ton. Menurut Lasco, (2002) yang dikutip oleh Junaedi (2007) menyatakan bahwa untuk tingkat vegetasi, potensi cadangan karbon di hutan tropis Asia berkisar antara 40-250 Ton/Ha.

Peningkatan cadangan karbon dapat dilakukan dengan meningkatkan pertumbuhan biomassa hutan secara alami, menambah cadangan kayu pada hutan yang ada dengan penanaman pohon atau mengurangi pemanenan kayu, dan mengembangkan hutan dengan jenis pohon yang cepat tumbuh. Karbon yang diserap oleh tanaman disimpan dalam bentuk biomassa kayu, sehingga cara yang paling mudah untuk meningkatkan cadangan karbon adalah dengan menanam dan memelihara pohon.

\section{Kesimpulan}

Berdasarkan hasil penelitian pada kawasan Arboretum Sylva Universitas Tanjungpura dapat di tarik kesimpulan sebagai berikut:

1. Karbon tersimpan (Carbon Stock) pada pohon yang masih hidup di Kawasan Arboretum adalah 817,76 Ton dan Karbon tersimpan per satuan luas di Kawasan Arboretum adalah 255,55 Ton/Ha.

2. Karbon tersimpan (Carbon Stock) pada pohon mati (Necromassa) di Kawasan Arboretum adalah 235,67 Ton dan Karbon tersimpan (Carbon Stock) pada pohon mati (Necromassa) per satuan luas di Kawasan Arboretum adalah 180,42 Ton/Ha.

\section{Saran}

1. Dengan adanya penelitian kandungan karbon bagian atas permukaan tanah (above ground biomass) di kawasan Arboretum Sylva Universitas 
Tanjungpura, dapat dilakukan penelitian lebih lanjut mengenai kandungan karbon pada pool-pool karbon lainnya seperti karbon bagian bawah permukaan tanah, karbon pada tingkat semai, karbon pada serasah dan karbon pada tanah di kawasan Arboretum Sylva Universitas Tanjungpura.

2. Perlu mempertahankan keberadaan Arboretum Sylva Universitas Tanjungpura sebagai kawasan Konservasi.

3. Dengan melihat besarnya potensi dalam menyimpan cadangan karbon diharapkan agar dijaga kelestarian Arboterum tersebut sebagai aset dari Universitas Tanjungpura.

\section{DAFTAR PUSTAKA}

Arief 1994. Hutan: Hakikat dan Pengaruhnya Terhadap Lingkungan. Jakarta: Penerbit Yayasan Obor Indonesia.

Brown S. 2002. Measuring carbon in forests: current status and future challenges. Environmental Pollution 116 (2002) 363-372.

Chave J, Andalo C, Brown S, Cairns MA, Chambers JQ, Eamus D, Folster H, Fromard F, Higuchi N, Kira T, Lescure JP, Nelson BW, Ogawa H,
Puig H, Reira B, Yakamura T. 2005.

Tree Allometry and Improved Estimation of Carbon Stocks and Balance in Tropical Forest. Oecologia (2005) 145: 8799.

Hairiah K, Rahayu S. 2007. Pengukuran Karbon Tersimpan Diberbagai Macam Penggunaan Lahan. Bogor: World Agroforestry Centre ICRAF, SEA Regional Office University of Brawijaya, Indonesia.

Junaedi 2007. Dampak Pemanenan Kayu dan Perlakuan Silvikultur Tebang Pilih Tanam Jalur (TPTJ) Terhadap Potensi Kandungan Karbon Dalam Vegetasi Hutan Alam Tropika, PT. Sari Bumi Kusuma, Kalimantan Tengah. Tesis Pascasarjana Institut Petanian Bogor, Bogor.

Krisnawati H. 2003. Penyusunan Model Dinamika Struktur Tegakan Untuk Pendugaan Hasil di Hutan Alam Rawa Bekas Tebangan. Jambi.

Nazaruddin 1994. Penghijauan Kota. Jakarta: Penebar Swadaya.

Mansur I, Tuheteru DF. 2010. Кауи Jabon. Jakarta: Penebar Swadaya.

Sutaryo D. 2009. Penghitungan Biomassa Sebuah Pengantar untuk Studi Karbon dan Perdagangan Karbon. Bogor: Wetland International Indonesia Programme. 